Proceedings of the 2018 International Scientific Conference 'Economic Sciences for Agribusiness and Rural Economy' No 2, Warsaw, 7-8 June 2018, pp. 360-365

\title{
ECONOMIC PERSPECTIVE OF SHORT SUPPLY CHAINS
}

\author{
Sebastian Jarzębowski, Eng $\mathrm{PhD}^{1}$
}

Faculty of Applied Informatics and Mathematics,Warsaw University of Life Sciences - SGGW

\begin{abstract}
Within the framework of the paper, the author introduces issues connected to short food supply chains. There are many different forms of short food supply chains (SFSC), but they share a common characteristic of reduced numbers of intermediaries between the farmer or food producer, and the consumer. The growing interest in SFSCs is shown in the paper - this reflects mainly the consumer demand for quality and traceability, given the alarming health crises in food markets. From a customers' point of view, SFSCs transfer more complete information about the origin of the food and, for producers, SFSCs retain a higher share of added value. The overview on the impact of short supply chains is provided in the paper. The results of the analysis show that the supply chain may have some beneficial economic effects. It is noticed that the SFSCs have potential to increase farm value added (profit allocation), promote sustainable farming systems, diversify production and contribute to local economic development.
\end{abstract}

Keywords: short food supply chain, supply chain management, sustainable development JEL codes: Q01, Q13, Q18

\section{INTRODUCTION}

Agribusiness and food supply chains are transforming from the commodity system into a coordinated food system (Jarzębowski, 2013). This leads to competition between various supply chains and networks, and not only to competition between individual companies (Christopher, 1998; Lambert and Cooper, 2000). However, these trends of change require research to adapt old or to develop new models of food business and food markets. Primarily due to the instability of products and the need to improve product flow tracking on the food market, representatives of science recognized the importance of the supply chain management process in the agri-food sector (Hobbs and Young, 2000). In addition, consumers continuously increase their demand on food safety and its functionality, product diversity, packaging quality, and the quality of services and products (van der Vorst, 2000). The issue of environmental protection and the economy of sustainable development is also now more important. Sustainable development is a resource and society dependent (World Commission on Environment and Development, 1987). In the literature dealing with the issues of sustainable development, more and more attention is paid to the relationship between supply chains and sustainable development of the economy. For example, Kashmanian, Keenan and Wells (2010) found that leading companies are systematically increasing their activities in the field of environmental protection (Kashmanian, Keenan and Wells, 2010).

${ }^{1}$ Corresponding author: Nowoursynowska 166, 02-787 Warsaw, Poland, sebastian_jarzebowski@sggw.pl, +4822 5937288 
One should notices, that an increasing number of consumers are looking for alternative sources of food produced near their place of residence (Cicia, Cembalo and Del Giudice 2010; Nie and Zepeda, 2015). This dissemination of new forms of food distribution organization in recent years, called short supply chains, can be linked to the increasingly important role played by credibility-based goods in shaping consumer preferences. Indeed, the growing popularity of short supply chains should be attributed to the distribution model, which allows consumers to support local agriculture while adding fresh products to their diet (Uribe, Winham and Wharton 2012). The SFSCs can also be seen as a means to restructure food chains in order to support sustainable and healthy farming methods, generate resilient farm-based livelihoods (in rural, peri-urban and urban areas) and re-localize control of food economies (EIP-AGRI, 2015).

The goal of the paper is addressed to short food supply chains. In the paper, the author attempts to characterized the form of the SFSC and to give the overview on the economic impact of short supply chains. In the literature, once can notice a lack of research on the SFSCs, thus the paper fits in with current scientific trends. The research is granted by European Commission in form of research project 'Short supply chain Knowledge and Innovation Network - SKIN' (Horizon 2020 Programme). In the paper, the first step of the research is presented.

\section{SHORT SUPPLY CHAINS - THEORY AND PRACTICE}

Various definitions of SFSC are presented in the literature. The 'Short Supply Chain' is often used as an umbrella concept (Marsden, Banks and Bristow, 2000), assuming context dependent economic, sociocultural, policy, organisational characteristics, and having different impacts on local economies. The definitions of short supply chain are formulated under different criteria as: number of intermediaries, physical distance, social relations, knowledge exchange, locality and governance involvement. According to the European rural development regulation (1305/2013) a short supply chain means a supply chain involving a limited number of economic operators, committed to co-operation, local economic development, and close geographical and social relations between producers, processors and consumers. This definition is used in the further analysis in the paper. The number of intermediaries is often used as a discriminating factor to define SFCS. Parker (2005) for instance, characterizes SFSCs by the very small number (or even the absence of) intermediaries between the producer and the consumer, as well as by the short geographical distance between the two.

On the base of the criteria outlined above, a great variety of SFSCs can be identified and various classifications or typologies developed. Such classifications are useful for a more systematic exploration of SFSCs and development and implementation of necessary support measures (Galli and Brunori, 2013). The EC IMPACT project (Marsden, Banks and Bristow, 2000; Renting, Marsden and Banks, 2003) proposed three main types of short food chains on the basis of the number of intermediaries, physical distance and organisational arrangements: Face-to-face, proximate and spatially extended SFSCs. According to Mundubat (2012) SFSC can be classified on the basis of the level of compromise (low, medium and high) that may be adopted either by consumers or producers into nine categories (Fig. 1).

The CROC project (Chaffotte and Chiffoleau, 2007) found it useful to distinguish between individual and collective, direct and indirect (with one intermediary) SFSCs. Whereas, the European Network for Rural Development in their report on SFSCs have identified three types of SFSCs on the basis of their individual or collective organisation and initiators (consumers and producers): direct sales by individuals, collective direct sales, partnerships of producers and consumers (Peters, 2012).

Short supply chain practices are becoming increasingly common across Europe as well as around the world. Currently in Europe there are many examples and types of short food supply chains. Usually these are small enterprises with limited local impact. However, these small initiatives indicate that these enterprises are able to provide solutions to improve the profitability and stability of agricultural producers. Therefore, there is a great need to identify, syn- 


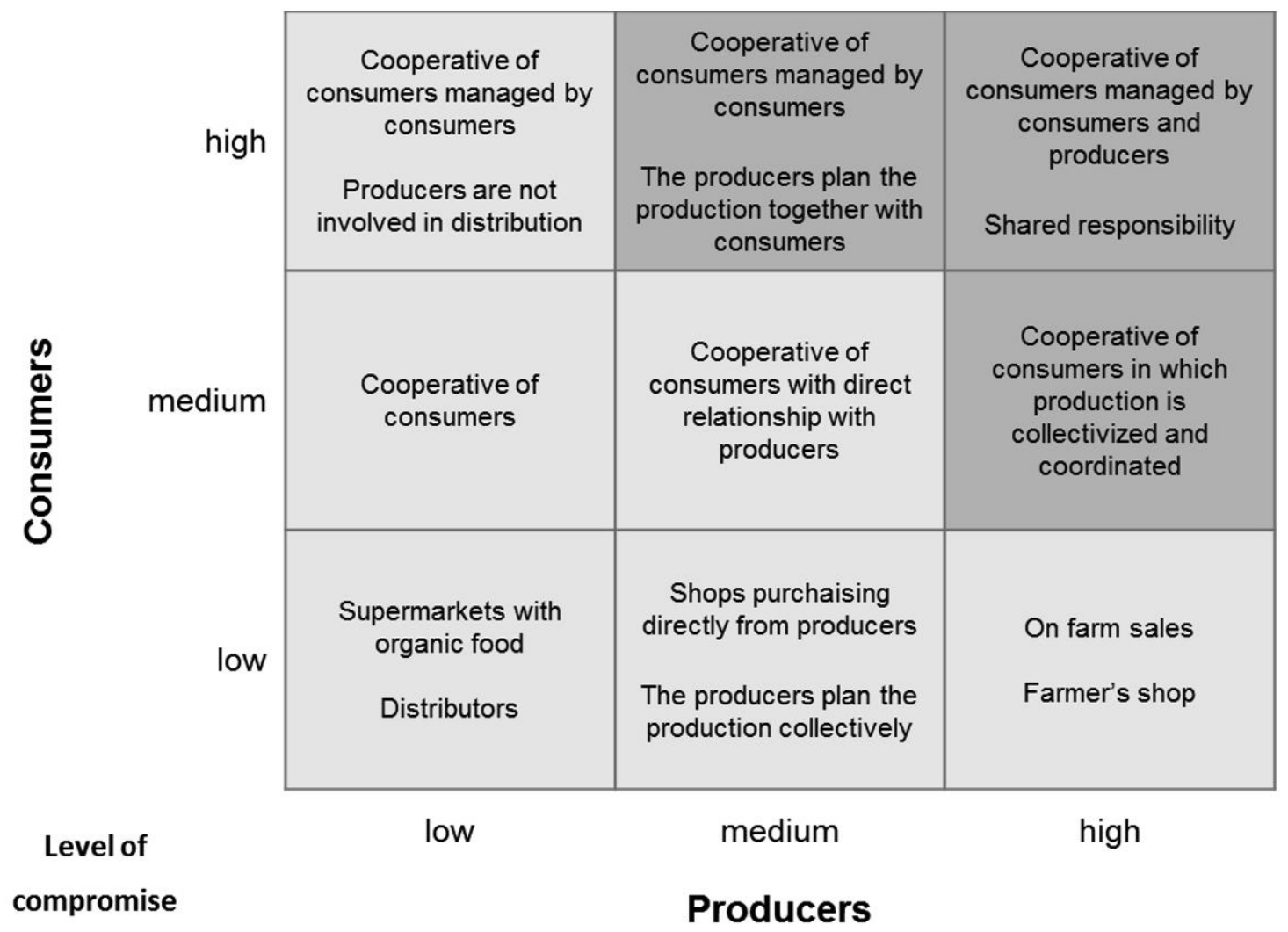

Figure 1. SFSC classification based on level of compromise between producers and consumers

Source: own work based on Mundubat (2012).

thesize, exchange and present good practices ${ }^{2}$ in the short food supply chains management with focus on small enterprises. These arguments were the basis for identifying examples of such chains in Europe. For this purpose, good practices regarding short chains in 15 European Union countries were analysed within the framework of the referred SKIN project. As part of the study, over 100 examples of initiatives were described and classified in specific sectors (Fig. 2).

The majority of good practices for short chains have been identified in Austria, Ireland, the United Kingdom and Hungary. In the analysed examples, there is a tendency to include more than one agrifood sector within a single enterprise. These practices include, for example, distribution solutions for agri-food products, such as on-line sales with home delivery or collection at designated places, or inviting consumers to farms to make a purchase. In Poland, the most practices related to the fruit and vegetable sector have been identified, while in Ireland - within the meat sector.

The concept of short supply chains concerns many of its participants who can benefit from shortening the path to the consumer. Almost all identified (within the framework of the referred SKIN project) good practices include a link of producers. In the case of one third of the analysed examples, there are processors of agri-food products and retailers. Labs, farm stores, tourism providers and wholesalers play a marginal role in the case of short chains.

\footnotetext{
${ }^{2}$ A good practice is not only a practice that is good, but a practice that has been proven to work well and produce good results, and is therefore recommended as a model. It is a successful experience, which has been tested and validated, in the broad sense, which has been repeated and deserves to be shared so that a greater number of people can adopt it (FAO, 2018).
} 


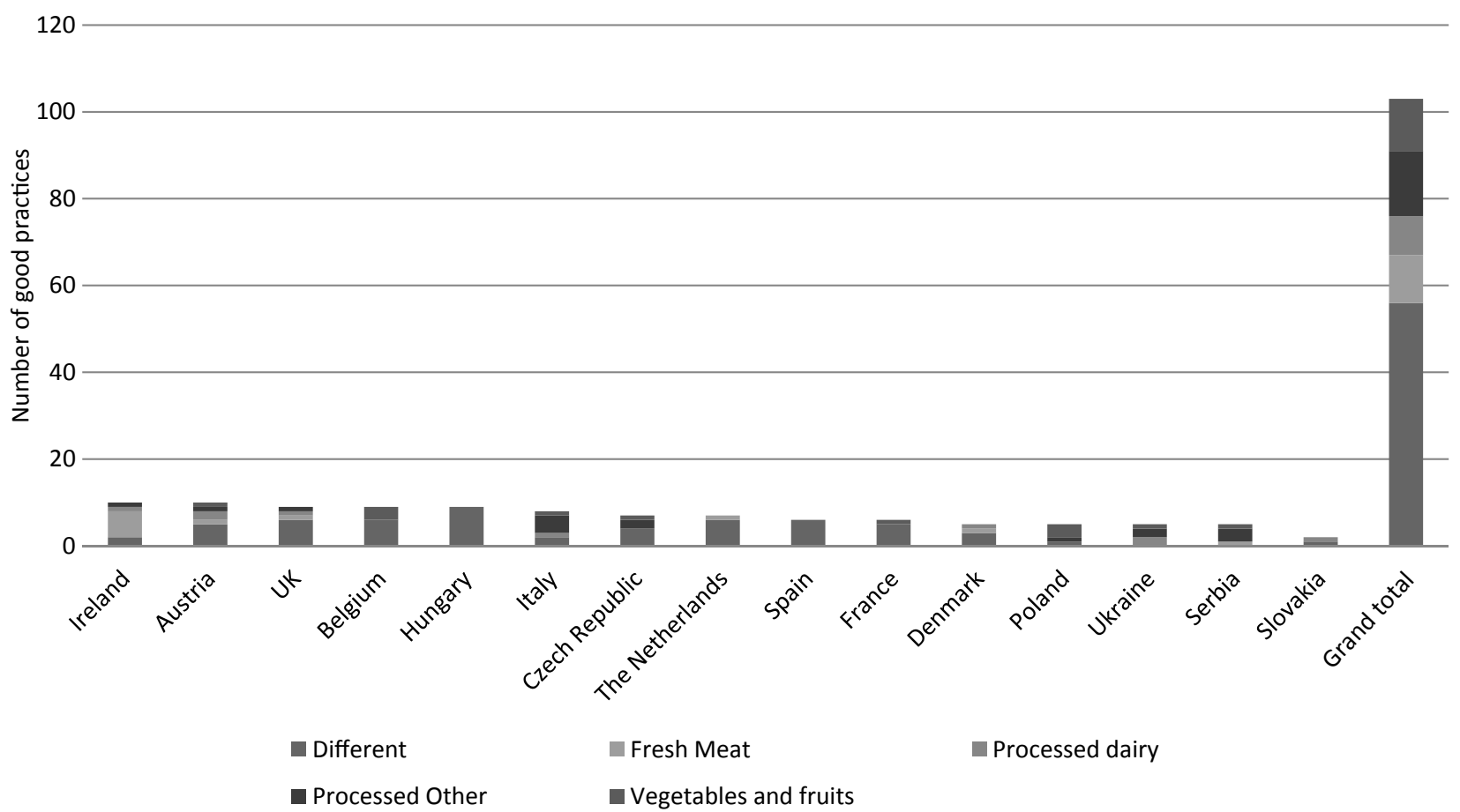

Figure 2. Good practices of SFSC in EU by sector

Source: own work based on results of project SKIN, Horizon 2020.

Within the framework of the SKIN project, topics that emerged in the researched good practices were classified into 4 main groups (products, organizational/institutional/systems, governance and sales). The first group concerns topics connected with product and is divided into following areas: Branding \& Labelling, Valorisation, Value (e.g. taste, healthiness), values, as social, economic and environmental sustainability. Social sustainability emphasis: trust, sense of community, connection between producers and consumers, community education, consumer empowerment, recognition of producers. The economic sustainability includes: profitability, synergies with other sectors, generating local employment, training and coaching initiatives. The environmental sustainability takes into account: food waste, GHG emissions, energy use and carbon footprint, food miles.

The first results of the analysis conducted within the project show that shortening the supply chain may have some beneficial effects on the environment, economy and society. However, it should be noted that the way in which the supply chain is shortened is important. Not necessarily all short chains will bring the expected benefits. For example, if production and distribution systems in the supply chain are not geared to sustainable development, the short supply chain will not bring the expected economic, social and environmental benefits.

\section{ECONOMIC BENEFITS OF SHORT FOOD SUPPLY CHAINS}

In the paper, the economic impact of SFSCs was in focus, thus the further part refers only to that area of influence. The research was conducted within the framework of the referred European project.

One of the most commonly reported economic benefits associated with LFS/SFSCs, is that of increased income for the producer, it is possible to obtain higher margins by farmers with lower overheads compared to the longer supply chains. It has been suggested that producers are able to add a price premium when selling through SFSCs (Pearson et al., 2011), that the elimination of the 'middleman' enables farmers to receive 
a greater share of the profits (Sage, 2003). Due to the implementation of short supply chains, there are more opportunities to negotiate contracts, ensure fair contract terms and to expand on a larger scale and enter new markets. An important role in this context is played by the use of modern distribution channels, i.e. dynamically developing e-commerce (e-shopping). The range of products can be varied and / or increased, so one can involve more producers and create more jobs.

In addition, SFSCs provide growers with an opportunity to diversify and add value to their produce that would not usually be marketed (Alonso, 2011). Despite these claims, which are numerous in the literature, few are supported by empirical research.

Of the studies which do present supporting evidence, the majority of evidence is qualitative, and based on perceptions and experiences. For example, when traders at a farmers' market in New Zealand were asked, in an unprompted way, to supply their reasons for using the market, the main motivation identified was for the 'economic' benefits (Lawson et al., 2008). Specifically, the perceived economic benefits were, "the desire to obtain a fair price, the wish to avoid middlemen and to obtain a supplementary income' (Lawson et al., 2008).

Economically speaking, benefits can be found in rural development and economic regeneration. There is evidence that local farming systems and short chains do have a higher multiplier effect on local economies than long chains, with impacts also on maintaining local employment, particularly in rural areas. The synergies with the tourism sectors are also well acknowledged. At producer and farm level, they seem to allow a higher share of value added to be retained locally, although quantitative evidence of such impacts is poorly documented.

Another advantage of short supply chains is that producers can share resources, i.e. equipment or logistics services to improve efficiency and share costs. Knowledge and skills can also be shared (using the strengths of different participants in short supply chains). Cooperation within short chains can help to integrate new actors in the chain with the agri-food sector. In addition, the maintenance or restoration of local processing plants, such as slaughterhouses or agricultural stores, becomes more real.
In addition, the requirement for higher labour input with different skills (production, processing, marketing, promoting) is a difficulty at farm level, particularly for small scale producers. The small scale of the schemes at stake and possible higher costs of production as a consequence can also be a threat for their longevity. Also, there are many examples of farmers using a mix of SFSCs, or combining them with longer chains in order to build resilient routes to market and reduce risks from market volatility.

\section{CONCLUSIONS}

Short Food Supply Chains (SFSCs) have established in parallel to conventional food chains, playing a key role in the emerging food networks that are continuously arising as an alternative to the globalized agri-food model. Due to the benefits of SFSCs, an increase in the number of initiatives supporting the development of such activities in the agri-food sector is noticeable. These models have become an alternative to the globalized structure of the agri-food sector, enabling 'bringing together' the two extreme links of the supply chain and satisfying the needs of both the consumption and production side, while affecting the well-established concept of sustainable development. Within the framework of economic perspective it can be concluded that short supply chains support achieving benefits as: higher margins/lower overheads (the often high costs charged by distributors can be split fairly between producers and consumers), improved product range (the product range can be diversified and/or increased so that more producers can be involved and more jobs can be created through retaining the added value in each territory), resource sharing (knowledge and skills, equipment, tools, processing facilities, transport and logistics can be shared in order to improve efficiency and share costs. can also be shared), improving local food chain infrastructure (retaining or reinstating local processing facilities such as abattoirs or farmers'shop), increased negotiating power (more weight in contract negotiations, ensuring fair terms and conditions, gaining access to public and larger scale markets), reduced competition (between many small uncoordinated SFCs in a region), mutual support: collaboration can combat isolation felt by small-scale producers. 
Concluding, it is required for small farms and agricultural producers to cooperate within integrated short chains in order to increase farm value added (profit allocation), promote sustainable farming systems, diversify production and contribute to local economic development.

\section{Acknowledgements}

The paper was prepared within the framework of research granted by European Commission within Horizon 2020 Programme as a project 728055 'Short supply chain Knowledge and Innovation Network - SKIN'.

\section{REFERENCES}

1. Alonso, A. (2011). Farmers' involvement in ValueAdded Produce: The Case of Alabama Growers. British Food Journal, 113 (2), pp. 187-204.

2. Chaffotte, L., Chiffoleau, Y. (2007). Vente directe et circuits courts: évaluations, definitions et typologie [Direct sales and short circuits: evaluations, definitions and typology]. Cahier de l'Observatoire CROC 1. INRA, Montpellier.

3. Christopher, M. (1998). Logistics and supply chain management: strategies for reducing cost and improving service. Financial Times Pitman Publishing, London.

4. Cicia, G., Cembalo, L., Del Giudice, T. (2010). Consumer preferences and customer satisfaction analysis: A new method proposal. Journal of Food Products Marketing, 17 (1), pp. 79-90.

5. EIP-AGRI (2015). Innovative food supply chain management. Final report 2015. Retrieved from: ec.europa. eu/eip/agriculture/sites/agri-eip/files/eip-agri_fg_innovative_food_supply_chain_management_final_report_ 2015_en.pdf [Accessed 5.05.2018].

6. FAO (2018). Good Practices. Retrieved from: http:// www.fao.org/in-action/kore/good-practices/en/ [Accessed 30.07.2018].

7. Galli, F., Brunori, G. (2013). Short Food Supply Chains as drivers of sustainable development. Evidence Document. Document developed in the framework of the FP7 project FOODLINKS (GA 265287).

8. Hobbs, J.E., Young, L.M. (2000). Closer vertical coordination in agri-food supply chains: a conceptual framework and some preliminary evidence. Supply Chain Management: An International Journal, 5 (3), pp. 131-143.
9. Jarzębowski, S. (2013). Integracja łańcucha dostaw jako element kształtowania efektywności sektora przetwórstwa rolno-spożywczego [Integration of supply chain as a factor of efficiency of agri-food processing sector]. Wydawnictwo SGGW, Warszawa.

10. Kashmania, R., Keenan, C., Wells, R. (2010). Corporate environmental leadership: Drivers, characteristics, and examples. Environmental Quality Management, 19 (4), pp. 1-20.

11. Lambert, D.M., Cooper, M.C. (2000). Issues in supply chain management. Industrial Marketing Management, 29 (1), pp. 65-83.

12. Lawson, R., Guthrie, J., Cameron, A., Fischer, W.C. (2008). Creating Value through Cooperation: An Investigation of Farmers' Markets in New Zealand. British Food Journal, 110 (1), pp. 11-25.

13. Marsden T.K., Banks J., Bristow, G. (2000). Food supply chain approaches: exploring their role in rural development. Sociologia Ruralis 40, pp. 424-438.

14. Mundubat (2012). Circuitos Cortos de comercialización en Euskal Herria.

15. Nie, C., Zepeda, L. (2011). Lifestyle segmentation of US food shoppers to examine organic and local food consumption. Appetite, 57 (1), pp. 28-37.

16. Parker, G. (2005). Sustainable Food? Teikei, co-operatives and food citizenship in Japan and in the UK. Working Paper in Real Estate and, Planning 11/05.

17. Pearson, D., Henryks, J., Trott, A., Jones, P., Parker, G., Dumaresq, D., Dyball, R. (2011). Local Food: Understanding Consumer Motivations in Innovative Retail Formats. British Food Journal, 113 (7), pp. 886-899.

18. Peters, R. (2012). Local Food and Short Supply Chains. EU Rural Review 12.

19. Renting, H., Marsden, T.K., Banks, J. (2003). Understanding alternative food networks: exploring the role of short food supply chains in rural development. Environment and Planning, 35 (3), pp. 393-411.

20. Sage, C. (2003). Social Embeddnedness and Relations of Regard: Alternative 'Good Food' Networks in South West Ireland. Journal of Rural Studies, 19, pp. 47-60.

21. Uribe, A., Winham, D., Wharton, C. (2012). Community supported agriculture membership in Arizona. An exploratory study of food and sustainability behaviours. Appetite, 59 (2), pp. 431-436.

22. Vorst, van der, J. (2000). Effective food supply chains; generating, modelling and evaluating supply chain scenarios. Wageningen University, Wageningen.

23. World Commission on Environment and Development (1987). Our Common Future. 